\title{
ENTREPRENEURSHIP AND ACTIVATION OF LOCAL POTENTIAL FOR RURAL DEVELOPMENT. LEMNIA AND SÂNCRAIU - TWO CASE STUDIES FROM ROMANIA
}

\author{
Kinga Xénia HAVADI-NAGY \\ Babeş-Bolyai University, Cluj-Napoca, Faculty of Geography, ROMANIA \\ xenia.havadi@geografie.ubbcluj.ro \\ Tihamér-Tibor SEBESTYÉN \\ Babeş-Bolyai University, Cluj-Napoca, Faculty of Geography, ROMANIA \\ sebesten_tiha@yahoo.com
}

DOI: http://dx.medra.org/10.23740/TID120161

\section{ABSTRACT}

The objective of this paper is to contribute to the discussion regarding challenges and possibilities of entrepreneurship in rural areas. First, we presented the attributes of the rural environment and the general characteristics of the rural population, which determined the prospects of generating entrepreneurship. Then, we focused on the local development strategies of two rural communities featuring entrepreneurship based on the activation of the local resources, with a participative approach and involving social capital and foreign know-how, or even capital. We concluded the investigation with some final remarks that could serve as policy recommendations for participative actions and endorsement of different scales of entrepreneurship targeting the development of rural areas.

Keywords: social capital, participative development strategies, entrepreneurship, rural areas, know-how transfer

\section{INTRODUCTION}

Population decline is often associated with decline in employment and amenities. In thinned rural areas affected by depopulation and aging, economic decline and shortage of public funds, it is increasingly difficult to maintain adequate infrastructure, educational and medical facilities and further public services, and ensure amenities for the remaining population (Faber \& Oswalt, 2013; Delfmann et al., 2014, pp. 1034-1050). In post-socialist countries, such as Romania, these phenomena are intensified by the multiple political, social and economic transformations which these countries are undergoing in the last decades. The increase of unemployment, caused by significant structural changes in the economy, is characteristic, in rural areas, in particular for the share of population former active in agriculture. The still mostly precarious situation of the infrastructure and services complements the general poor image and low development of the rural areas (Ministry for Agriculture and Rural Development, 2013, 2015).

One main objective of the Romanian rural development policies is the social and economic revitalisation of the rural space (Ministry for Agriculture and Rural Development, 2013, 2015). Numerous strategies and measures target the diversification of employment and income possibilities on the one hand, by promoting modern agriculture, and, on the other hand, by introducing different non-agricultural activities, in order to ensure their sustainability and to diversify and cope with risk. 
The practical relevance for this research is given by the undergoing discussion on strategies engaged against the decline of the rural areas and the chances of participative development endeavours. The development of villages depends primarily on a well-functioning economic and community life. Entrepreneurship is considered to play a major role in maintaining the quality of life in declining regions, not only from the economic point of view, but also on social and community level, creating trust and maintaining social relations (Delfmann et al., 2014, pp. 10341050). Economic development, being highly related to the abundance of small entrepreneurial firms and regional change, supposed to be the result of innovative entrepreneurial activity (Pijnenburg \& Kholodilin, 2014, pp. 866-882), and measures to support entrepreneurship are significant in every development policy. The objective of this paper is to contribute to the discussion regarding challenges and possibilities of entrepreneurship in rural areas, by presenting two case studies focusing on rural communities in Romania, and to tackle the transferability of these approaches.

Current research argues that individual entrepreneurs need a network of supporters and that social capital has an impact on entrepreneurship, affecting the disposition to initiate a business (Westlund et al., 2014, pp. 974-994). Hence, in our research, we focused on the local development strategies of two rural communities featuring entrepreneurship based on the activation of the local resources, with a participative approach, and involving social capital and foreign know-how, or even financial capital.

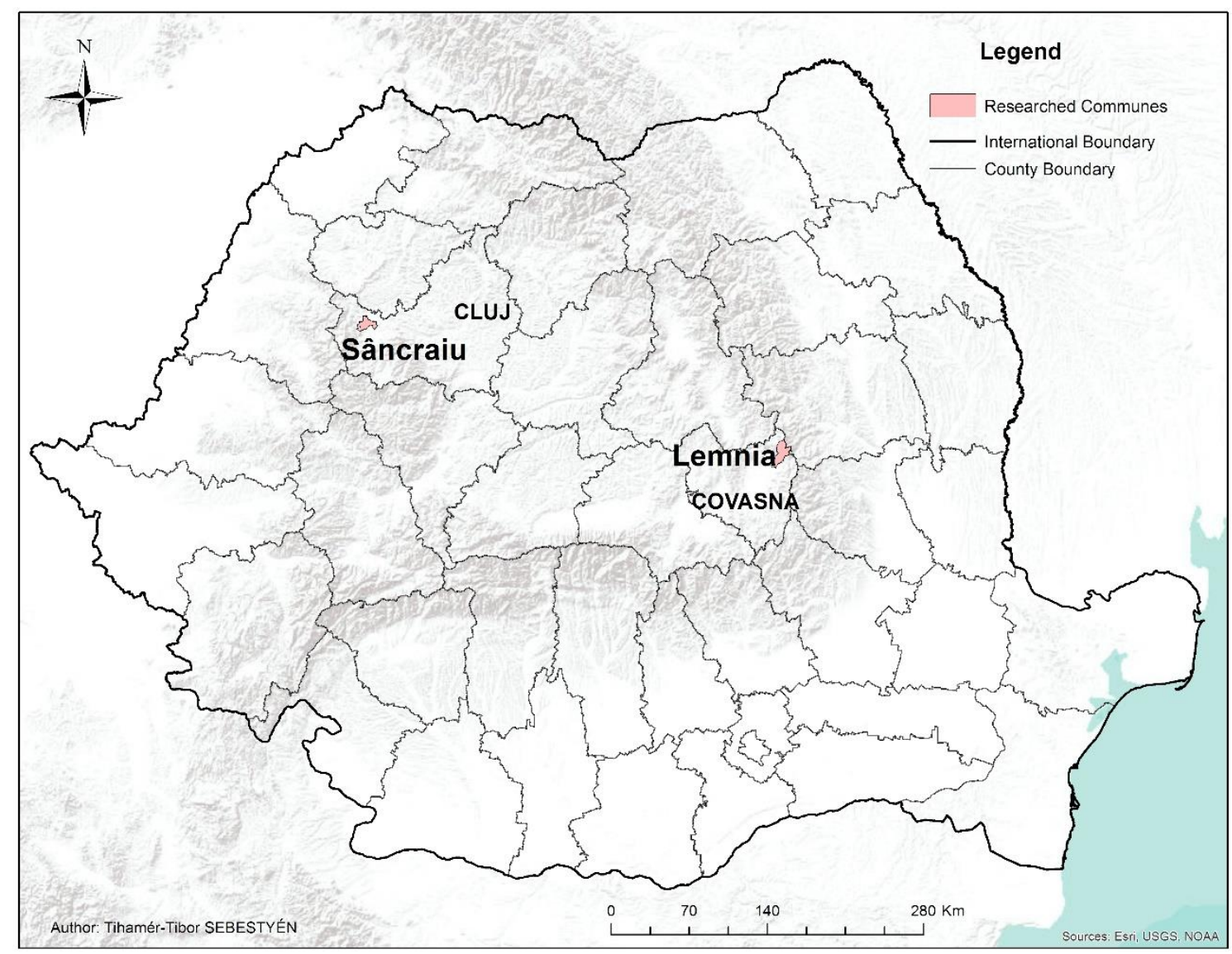

Figure 1: The location of the investigated communes in Romania: Sâncraiu in Cluj County and Lemnia in Covasna County, 2016 
The problems of the rural areas in Romania rest on less investment, less subsidies, underperforming agriculture, out-migration, lack of human capital, insufficient supportive and advisory structures and a missing overall development vision (Jordan et al., 2016, pp. 203-218). In this context, our case studies are both good practice examples for the ability to identify opportunities for their development and in promoting a necessary social change. Lemnia (Hungarian: Lemhény), a commune in Covasna County, and Sâncraiu (Hungarian: Kalotaszentkirály), a commune in Cluj County (Figure 1), represented to a certain extent different approaches, but both demonstrated the possibilities that know-how transfer, innovative entrepreneurship, and personal relationships based on trust or friendship had for the development of rural communities exploiting the local human and natural potential.

Our final remarks might serve as policy recommendations for participative actions and endorsement of different scales of entrepreneurship targeting the development of rural areas.

\section{METHODOLOGY}

This research is based mainly on the qualitative data we collected between 2013 and 2016, during repeated research field trips in the two study areas. Interviews and round table discussions with various involved stakeholders (representatives of the public administration, of local associations and institutions, entrepreneurs, project initiators and further locals and foreign settlers) provided us with qualitative information. On site observation over the years completed the collected primary data and allowed the follow up of the progress of the projects and applied strategies. Quantitative official statistical data rounded up our findings.

\section{RESULTS AND DISCUSSION}

Being a multi-dimensional concept, the literature provides numerous definitions of "entrepreneurship". The Green Paper Entrepreneurship in Europe (Commission of the European Communities, 2003) combines the economic and management perspectives of the notion: "Entrepreneurship is the mindset and process to create and develop economic activity by blending risk-taking, creativity and/or innovation with sound management, within a new or an existing organisation" (p. 6).

Other definitions tend to focus on one or another aspect, such as the innovative one, related to a rapid and high growth potential that has a particularly strong contribution to economic development. However, in many rural and disadvantaged areas, a mix of businesses with high growth potential and those shaped by life style purposes, or self-sufficiency that primarily serve local needs are required to support the sustainability of rural communities (Smallbone, 2009, apud Wennekers \& Thuri, 1999; Zacharis et al., 2000; Dabson, 2001).

There are many regional aspects that can contribute or can hinder the business formation (Fritsch \& Wyrwich, 2014, pp. 955-973). Regional social capital, attributes of regional networks and regional entrepreneurial history are significant for a region's level of entrepreneurship. Entrepreneurial culture is part of the social structure which is deeply embedded in a population and tends to be quite persistent. Still, successful examples and role models could lead to a positive change in the characteristic regional attitude toward entrepreneurship, and, at the same time, increase the social acceptance of entrepreneurship and raise the possibility of adopting entrepreneurial lifestyle (Fritsch \& Wyrwich, 2014, pp. 955-973; Kibler et al., 2014, pp. 995-1015). 
In his survey conducted for the OECD about fostering entrepreneurship in rural areas, Smallbone (2009, pp. 161-187) identifies distinctive attributes of the rural environment which affect entrepreneurial activities: (1) the small size of local markets (due to low population densities, and low per capita and household incomes); (2) characteristics of rural labour markets (mainly narrow occupational spectrum of rural labour markets, limited access to skilled labour force); (3) the availability of business premises (on the one hand, the cost of premises in rural locations could be smaller than in urban areas, but, on the other hand, growing businesses may have trouble finding larger premises within a short distance of their existing location); (4) transport and communication infrastructure (the remoteness of many rural places presents transportation challenges); (5) access to information, advice and business services (greater average distance from business advice and support services; poorer quality of the business services); (6) access to finance (limited access to capital and bank loans); and (7) the institutional environment (creation of proper education and training infrastructure to support entrepreneurship; support from public administration).

He also states that the prospects of generating entrepreneurship are influenced not only by the rural environment, but also by several characteristics of the rural population, as preconditions required for their implication in such endeavours: (1) the development of an enterprise culture and attitude (rural areas are characterised by distinctive socio-cultural values and attitudes that can affect small business development, through its influence on gender roles, co-operation, communications and network composition); (2) the nature and extent of social capital, which can be an important potential resource for enterprise development (social capital in rural areas is based on the interaction between individuals in formal and informal networks, involving social trust); (3) the role of in-migration (in-migration can contribute to increase the entrepreneurial capacity of a rural region, either directly, if immigrants start up new ventures themselves, or indirectly, if they make their experience available to other entrepreneurs) (Smallbone, 2009, pp. 161-187).

In post-socialist countries, such as Romania, these general aspects are completed by consequences of the transition: (1) challenges of the economic, social and political structural changes; (2) discontinuous entrepreneurial culture and tradition; (3) lack of education and training infrastructure to support entrepreneurship; (4) limited capacity of rural areas to generate entrepreneurs; (5) social capital being a significant element for the socio-economic welfare of rural communities going through the transition to a market-oriented economy (Havadi et al., 2015, pp. 19-30).

In our investigated communes, we may notice the activation of local entrepreneurial potentials, yet there are several differences: in the case of Lemnia, we focus on market oriented entrepreneurship in agriculture and food processing sectors and, in Sâncraiu, we underline initiatives of social entrepreneurship and a well-functioning touristic endeavour, as a mix of businesses for a sustainable development of the respective communities.

\section{Lemnia - market oriented entrepreneurship}

This subchapter focuses on Lemnia as the core of the regional entrepreneurship, but includes further settlements which form the main catchment area of these economic initiatives, either as suppliers of manpower or raw material, or as distribution area of final products and services. Lemnia was one of the case studies of a recent research (Havadi et al., 2015, 19-30) focussing on possible development strategies adopted in less-favoured areas, affected by specific natural and 
socio-demographic handicaps. Referring to those findings, our investigation completes the conclusions, but emphasises significantly on the success factors of entrepreneurship, and includes also the latest developments, the outcome of a follow-up survey.

Lemnia - a commune in the north-eastern part of Covasna County (Figure 1) - lies along the river named Rîul Negru, at the meeting point between the hilly area of the Nemira Mountains and the Târgu Secuiesc Depression. According to National Institute of Statistics (INSSE), the commune is $95.05 \mathrm{~km}^{2}$ large and the population census of 2011 registered 1,936 inhabitants, from which the majority $(1,836)$ declared to be Hungarian ethnics and the others were Romanians and Roma.

The commune struggles with the general economic, social and demographic challenges valid for the rural areas in Romania. However, it exhibits also some successful ventures established, on the one hand, upon foreign work-experience and "know-how" transfer of agricultural technology, but also on entrepreneurship based on opportunity and on valuable local potential.

Beginning with 1992, several young people from the village had the opportunity to attend an internship on farms in Switzerland or Germany and get acquainted with modern farming technologies and processes. The foreign know-how in modern agriculture and the expertise in entrepreneurship acquired during repeated stays on these farms resulted in several marketoriented agricultural incentives established by the participants at this programme. These motivated young people got inspired by their experience and the insight they gained into one or two specific occupations and, at their return, they demonstrated a higher degree of entrepreneurship and the willingness to apply the knowledge and experience they attained at the farms they worked while abroad. Thus, some cattle farming with dairy business, several crops growing farms and a goat farm for milk production came to life. For example, in 2009, one of the young farmers initiated sugar beet production after having worked on a Bavarian sugar beet farm. The microclimate of Lemnia is actually ideal for the cultivation of this crop, and can be marketed under sure contractual conditions. After their Swiss experience and fundraising, several young men started up cattle breeding ventures, as Lemnia has suitable vast grasslands and pastures due to its mountainous relief. One of the cattle breeders acquired Simmental cattle and, since 2006, his livestock has been growing. In 2010, he built a new barn to accommodate 42 dairy cows and, at present, he also grows forage plants. He has a contract with the milk processing plant in Sfântu Gheorghe (Hungarian: Sepsiszentgyörgy). Another example for a successful venture is the goat farmer who started up in 2011, by purchasing 50 goats, from Sibiu County, a venture which by now has become larger. Goat farming was not typical for this region, but the idea was to target and develop such an occupation in which the market is not yet saturated. This is how he became the most important goat holder and the only goat milk producer in the neighbourhood, who also has a contract with the Sfântu Gheorghe milk processing enterprise. Extensive pig breeding by two farmers, since 2012 and 2014, has completed the variety of market-oriented animal husbandry conducted by young farmers.

Further natural potential is available and its exploitation is emerging and developing. The clean and mostly pollution-free mountain streams of the village enable fish breeding activities. Some locals recognised these possibilities, built small weirs and established fish ponds behind them. Alongside two bigger pond systems for trout and carp farming, there are several small private ponds. The village has also wet, swampy areas, where the groundwater level is too high throughout the year for crop production. Norwegian and Swedish models motivated young entrepreneurs to cultivate willow (Salix viminalis) and incorporate these inactive areas of high ground water level in the agricultural circuit. Already about 70 ha (data as of 2016) are used to grow this biomass plant, suitable for heating, with a great future as renewable energy plant. 
The forest is very rich in forest fruits and even in some rare mushrooms. Even though the demand for these products is increasing, these resources are not yet capitalised. For the moment, only occasional collection actions were organised and the Roma families are engaged in the collection and selling of the fruit, thus having a casual income. On the other hand, young farmers learning from their Swiss experience, since 2012 have started to cultivate mushrooms, medicinal plants, and various berries. Further resources bear the orchards mainly with apple and plum trees, the fruit being primarily for winter storage, as well as used for alcohol production in the active local distillery.

Not only the foreign know-how, but also foreign starting capital was an important factor for the successful undertakings. The biggest problem of young farmers is the capital-intensive modern agriculture technology. This issue cannot be always solved by applying for grants directed to rural or agricultural development, as most of the farmers lack the resources for down payments, for their own contribution, and they reject the possibility of bank credits or they do not trust them. It is because of these reasons that many of them rather considered the collaboration with a foreign farmer a fitting solution for the lack of starting capital. During the initial internship and later on, during the repeated seasonal employment of the young farmers over several years, a trust relationship developed between the Swiss or German farmer and the employee from Romania. More and more promising examples of well-functioning co-operation strengthen the will of the foreign farmers to start-up ventures or to co-operate with Romanian partners in trading or in agricultural business. Such kind of already existing collaborations show that they do not follow exclusively commercial purposes, but they are also facilitated by relationships based on trust and friendship with a win-win situation for the involved parties.

Beside these numerous market-oriented agricultural small and medium size enterprises (Figure 2) established thanks to the ability to seize and capitalise the possibilities offered by personal and informal relations, as well as thanks to the willingness to employ an innovative business approach and foreign know-how, Lemnia is the starting point for a significant large company of the region, too: S.C. Toro Impex S.R.L. The cornerstone of the company was the slaughterhouse (Figure 2) established in 1997, on the site of the former agriculture collective, which evolved to the county's only EU-compliant, licensed slaughterhouse, where also meat products are prepared. This local initiative benefited also from grants in the framework of the SAPARD (Special Accession Programme for Agriculture and Rural Development) programme, followed by EAFRD (European Agricultural Fund for Rural Development) financial support, which enabled modernising the facility and the processing department, as well as the furnishing with EUregulations compliant equipment. Veterinary certified farmers provide the raw material; whereupon the import of livestock is diminishing and the domestic farms (mainly from the region) growing capacities ensure a regular high quality supply. The meat products are mainly marketed in the neighbouring counties (Covasna, Harghita, Neamţ, Bacău, and Braşov), and the logistic of the products is managed with their own truck fleet.

The initial business with the slaughterhouse continuously developed and the company diversified its field of activity. Financial input in a saw mill and wood processing plant in Oituz, further one in a bakery in Breţcu (Hungarian: Bereck) facilitated the diversification of the company's profile, and maintained jobs in a peripheral rural area struggling with depopulation and unemployment. A modern pig breeding site has been functioning since 2015 . As the capacity of the new pig farm ensures only about $10 \%$ of the slaughterhouse needs, three other piggeries from the county produce and provide the raw material exclusively for this company. Further 22 pig breeders, mainly from Braşov, Bacău, and Buzău counties deliver high quality meat to be processed and distributed. Beside this piggery, the company runs also a small cattle breeding 
farm. Their own contracting business employs local manpower and executes the works on all the buildings, plants, workshops, and retail units of the company. The unit is often contracted also for works on public buildings (e.g. schools, kindergartens, and sport facilities) or for private assignments. A small water bottling plant exploits further local natural resources. Rich mineral content water is bottled and distributed not only in their own shop network, but is directed also to the regional market. In several villages, function retail units and, in the cities of the area (Târgu Secuiesc / Hungarian: Kézdivásárhely, Sfântu Gheorghe and Braşov), butcheries. This line of stores is different than the regular village shops, as many goods are provided from their own production units or from the region in general: vegetables are grown in Lemnia, a fish farm from Breţcu supplies fish, meat and meat products come from the slaughterhouse, milk from their own cattle and also bakery products from the bakery in Breţcu.

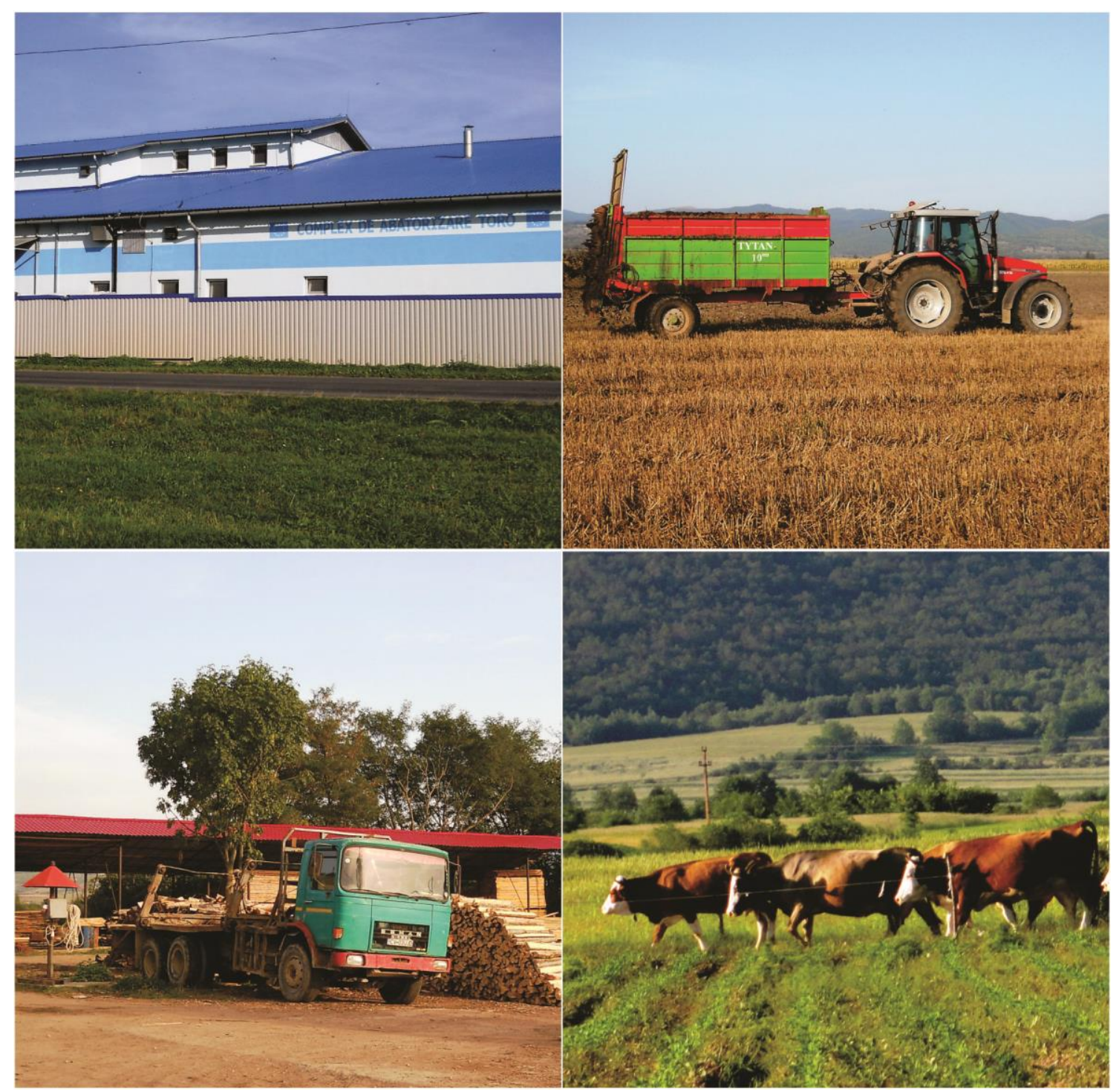

Figure 2: Lemnia - evidence of market-oriented economic practices: the slaughterhouse (top left of the picture), tractor at work (top right of the picture), the wood processing plant (bottom left of the picture), extensive cattle breeding (bottom right of the picture) 
This conglomerate of economic units employs altogether around 370 persons (numbers as of 2014), with a small seasonal fluctuation. Most of the people are from Lemnia and Breţcu, and the others mainly from Mereni (Hungarian: Kézdialmás), Estelnic (Hungarian: Esztelnek), Poian (Hungarian: Kézdiszentkereszt), and from Ojdula (Hungarian: Ozsdola). The economic and social connections with the local community and the region are yet more diverse. The company purchases large amounts of fodder from the local and regional farmers. Due to the need of large fodder amounts, the company aims to develop this co-operation into a contractual relationship with the suppliers. This would facilitate a sure market for the products of the small-scale farmers, who presently face troubles in the marketing of their crops. High quality livestock purchased from the farmers of the commune and neighbourhood graze during summer on the mountain pastures leased from the commune, which contributes to obtaining high quality meat and to ensuring satisfied and stable customers. This kind of co-operation is continuous and the small-scale livestock breeding farmers have a sure buyer for their merchandise. The company places its agricultural vehicle park at the disposal of the regional farmers. Further on, it offers financial support, sponsorship for community activities and events, for youth programmes, scholarships, culture, and for sports events. Worth to mention is also the company canteen for the employees, who receive two meals a day, complementary to their wages. The canteen is supplied mainly from their own agricultural production units.

The concept of the company's management model is based on coordinated development and balanced support of the various local and regional potential of the rural communities. Recognizing the latent capacities in the commune, the company's business policy aims to generate in-house most of the raw material processed on their own production sites. Securing the continuous flow of high quality raw material, mainly from the region, enables a constant operation of the processing plants and thus the formed clientele receives regularly local and quality-controlled goods. The independence from external suppliers creates a safe and stable, more sustainable operation and performance of the company.

A multi-pillar approach has strategic importance in the market economy. In addition to the diversification of the local products, more and various jobs are created. So far, the vertically integrated production-processing-marketing system relies on eight profiles (animal breeding and meat processing, vegetable and crop cultivation, grocery network, logging, construction, bakery, and water bottling). The long-term economic viability of these businesses is obvious, as they are based on the local resources, with the strategic aim to develop them further on. The company is well integrated into the regional and national business networks. Very important is also the relationship with the employees, the co-operation with them and the workers' confidence in the company, the fact that they identify with the goals of the management team; thus, the enterprise is functioning well and the productivity increases. The company takes care also of the human capital and it established professional training programmes to upgrade the local human resources and capacities. The meat processing plant created a partnership with the educational centre in Breţcu and, beginning with 1994, they set up a butcher and meat processing vocational programme. During the three years of training, several dozens of professionals are instructed and, currently, many of them are employed as qualified personnel at the slaughterhouse and at the meat processing plant. The expanding need of butchers ensures a constant flow of trainees; thus, the co-operation with the educational institutions is meaningful.

In addition to the new ventures, very important is also the modernisation and constant improvement of the existing facilities to provide high quality products so as to maintain the competitiveness. For example, the wood processing unit is currently undergoing a process of 
modernisation and diversification of products (e.g. boards, beaverboards, raw material for paper, parquetry). The company implements also environment-friendly innovative heating systems - a biomass-energy facility based on the chip from their own saw mill, and a solar cell station - to cover the energy needs of the production facilities and infrastructure.

Beside the large company active in agriculture and agricultural products, a second major undertaking based in Lemnia is a logistic enterprise, providing foreign and domestic freight transports, which employs 15 workers. In addition, in the village, there are several microenterprises, such as a wood processing site and saw mill, a carpentry, and car mechanics.

As shown above, in Lemnia, there are several companies with positive perspectives in developing and diversifying employment and income possibilities in agriculture related and nonagriculture activities. This mix of businesses have further development possibilities, but a positive input to the economic and social evolution of the commune could be the opportunity to transform the strong personal relationships of several citizens to German and Swiss farmers into an official co-operation and partnership with a Swiss or German community. A larger and well-coordinated collaboration, based upon trust relations and networks, could contribute to the well-being of the whole community.

\section{Sâncraiu - developed tourism and social entrepreneurship}

As shown above, in the first case study, we have mainly examples for opportunity-driven entrepreneurship, based on the chance of benefiting on a larger input of foreign capital, but also on the implementation of EU financing possibilities and grants. Except for the major importance of social capital for the social and economic life of the community, the phenomena observed in Sâncraiu (Figure 1), are different on various levels.

The region between Huedin (Hungarian: Bánffyhunyad) and Cluj-Napoca (Hungarian: Kolozsvár), known by the Hungarian population as Kalotaszeg (Romanian: Călata), is one of the most peculiar Transylvanian areas. Traditionally inhabited mainly by Hungarian ethnics, it is a geographically, historically, and ethnographically defined particular region. Approximately 42 villages (depending on the criteria taken into account for regionalisation) form this region, where Hungarian culture persists, with ancient traditions, customs, and crafts. Sâncraiu (Figure 3) is one of the well-known settlements of this ethnographically particular region, due to its function as significant touristic destination of this area. The commune lies at $6 \mathrm{~km}$ from Huedin, at the fringe of the Apuseni Mountains, in a nice hilly scenery. Together with the other villages, which form the commune of Sâncraiu - Horlacea (Hungarian: Jákótelke), Domoşu (Hungarian: Kalotadámos), Alunişu (Hungarian: Mogyorókerék), and Brăişoru (Hungarian: Malomszeg) - the census from 2011 counted 1,633 inhabitants, with over $78 \%$ of Hungarian ethnics.

European rural development policies consider tourism a possible strong driving force in rural development and, in many cases, the only realistic economic opportunity. As seen above, despite some remarkable examples of cultural heritage, in Lemnia, tourism is marginal and local hospitality initiative insignificant. However, in the region of Călata in general and in Sâncraiu in particular, there is a significant natural and cultural potential that is exploited for touristic purposes and for the benefit of the community. A major impact on the development of the area as touristic destination had the yearly (since 1991) organised traditional dance and music festival, which contributed largely to the visibility and appreciation of the village. The tourism activity, based mainly on cultural heritage (built heritage, customs, traditional music, dances, and crafts), turned into a major initiative to diversify the locals' income possibilities. Remarkable 
is the organisation of the providers of touristic services in a well-functioning association, with yearly meetings (where they set the fees and prices, schedule the commune events, etc.), the use of a system for the fair distribution of the tourists, good online presence (see http://www.kalotaszeg-davincze.ro/en), and significant co-operation with several foreign and domestic travel agencies. This initiative and organisational system has a committed strong personality (the president of the association) as a driving force. Important is also the cooperation with the public administration, at least for the provision of infrastructure of all kinds (transportation, water supply and canalization, health care, and education), and also in maintaining a neat and pleasant villagescape (Figure 3).

The touristic offer is significantly focused on the Hungarian market, to which the village has special relations due to its distinct Hungarian past and still a remarkable share of Hungarian population. For example, this commune benefits also from the programme of the Hungarian Government, which supports school trips to regions formerly part of "Historic Hungary". Taking into account the political and economic sensitivity of tourism, the unilateral dependence on the Hungarian market could mean also a risk. Personal relations and networks contributed significantly to the promotion of the destination abroad, so larger groups of visitors are coming lately also from Latvia and Denmark. Networking - in the economic field, with the public administration, as well on a personal informal level, locally, regionally and internationally - is one of the major success factors of this initiative.

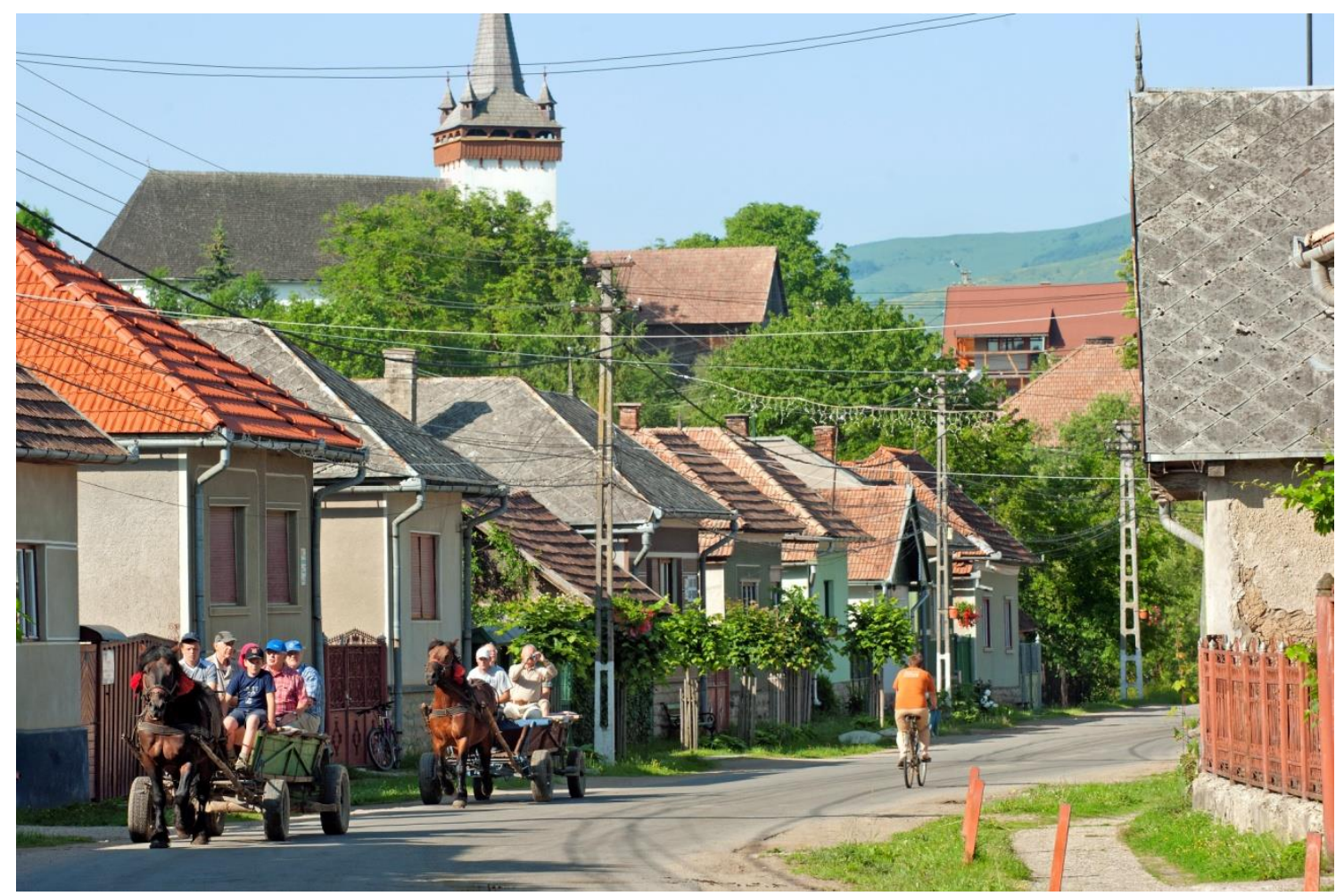

Figure 3: Sâncraiu - villagescape, 2014

Photo courtesy of Michael Schneeberger

This entrepreneurship in tourism activities originated mainly from locals - supported by the organisers of the dance festival - so a large part of the local population is directly engaged in touristic activities (mainly accommodation and catering) or benefits indirectly, to a larger or 
smaller extent, from them (transport company, grocery, gift shop, souvenir production, and selling of local products). Due to cultural tourism as a complementary source of income, inhabitants are also more motivated to protect and preserve cultural heritage, to maintain customs and various identity defining values of the commune. The village got attractive also for townsmen, who move to the village at least seasonally and many of them promote local initiatives, augment the tourism offer and establish new networks, supportive for the local tourism and community in general. With the co-operation of more villages, the municipality and the tourism association in Sâncraiu strive to access EU and national grants for larger projects, such as the delimitation of a bike road and the establishment of a nature trail. For these reasons, as demonstrated by Jordan et al. (2016, pp. 203-218) for other Romanian villages, this good practice endorses community based approaches to sustainable tourism and argues that local cooperation, trust and networking are elementary success factors. This approach needs, however, vision and leadership, entrepreneurial skills, access to credit facilities and the mobilisation of resources (Jordan et al., 2016, apud Manyara \& Jones, 2007; Petric, 2007).

Besides well-established tourism and a committed local administration, this settlement demonstrates also active citizenry organised in different associations focused on economy, culture, and environment. The commune benefits also from further initiatives, which do not originate explicitly from the village, but from the neighbouring villages, to which it has strong relations. In the neighbourhood of Sâncraiu, there are a few actors, mainly in-migrants originating from the Netherlands, the United Kingdom or from the USA, who, in the spirit of the rural space pioneers, demonstrate an innovative approach to the nature close, rather archaic way of life, and to the human and natural resources of the rural area.

Rural space pioneers are actors who spur on and promote social, organisational and technical innovations locally and regionally and thus provide possible solutions to socio-economic constraints. As summed up by Havadi (2014, pp. 263-276), in her research on the phenomenon of rural space pioneers in Romania, through their creative initiatives, these actors and micronetworks attempt to set new values in rural areas, which face a phase of economic, social and cultural upheaval; they develop customized solutions and promote self-responsibility through sustainable, feasible initiatives, based on co-operation and local resources; they act community oriented, according to the principle of inclusion, and endowing culture and regional identity (Havadi, 2014, apud Koalick, 2007; Faber, 2013; Veihelmann, 2013).

One of the successful ventures, "Gustare", initiated by two former English teachers from the United Kingdom, advocates for community supported agriculture based on a partnership between the famers in proximity and the urban consumers, and focuses upon creating opportunities for semi-subsistence farmers, even for subsistence farmers, who cannot benefit from EU or national grants. This alternative, locally-based economic model of agriculture and direct food distribution, is a direct selling without intermediary, a partnership established on solidarity. Small-scale farmers from about 10-12 villages (among which Domoşu and Alunişu) from the area provide the products (vegetables, homemade pasta, eggs, honey, seasonal fruits, cheese, and walnut oil) for the weekly boxes delivered to the consumers in Cluj. The order, collection, transport and delivery of the products is coordinated by the initiators and it works due to a system developed and improved in time with the involvement of the suppliers, of some villagers who help out with the harvest in the gardens, and even of the consumers from Cluj. The success of the project has resulted in a secure income of the participating semi-subsistence farmers and in the producers' well-being. 
Their initiative is based upon solidarity, responsibility, equality, fairness, and voluntariness, by that observing the main principles of social entrepreneurship ${ }^{1}$. The aim of this fair trade initiative, with weekly distribution system of traditional and ecological products, was to encourage local and regional agriculture, thus facilitating the persistence, or even survival of the semi-subsistence farmers challenged by the "turbo-capitalism". As social entrepreneurs, they are committed to the preservation of the tangible and intangible heritage, which they consider to be at risk as consequence of the structural upheaval faced by the rural space in general.

Besides the "Gustare" project, they also advocate for the preservation of valuable vernacular architecture and support the characteristic sewing and embroidery tradition in an innovative way, by applying the technique on modern objects (like bike bags or laptop covers), and making it attractive to a larger consumer group. With their efforts, the coordinators try to preserve the still existing nature close, humble life style and sense of community. Further on, by promoting local potentials, they attempt to improve and diversify the income opportunities of the locals (Havadi, 2014, pp. 263-276).

The most successful are the projects in co-operation with the locals, where all the interested parties bring in their ideas, knowledge, skills, and experience for a more sustainable initiative based on local resources. Compared to the start-ups in Lemnia, the foreign financial input is less significant, but the actions and initiatives of the in-migrants address to a larger group of people and ease various constraints, such as mobility issues through a car-sharing incentive, shortage of manpower in the case of the old inhabitants by voluntary work, or the support offered to smallscale and subsistence farmers. The foreign inhabitants value the rather archaic rural life style, with a low ecological footprint, and are open and eager to learn and acquire skills which make a basically self-sufficient life style possible. Even though, to some extent, the locals live under modest circumstances out of economic constraints, the in-migrants adopt this way of life by choice and out of conviction. So the exchange of know-how and skills is based upon reciprocity, to the benefit of both, locals and newcomers. As the political turn in 1989 induced powerful economic, social and demographic transformations, which endanger rural communities and their natural and cultural heritage, the interest of the settled foreigners towards local traditions, customs, values, skills, and knowledge contributes significantly to appreciating their own values, and endorse the communities to cherish and preserve them.

A further initiative is also an example of necessity-driven entrepreneurship. Because of various factors, but mainly because of the aging population and the EU restrictive regulations, many people in Alunişu, a village part of the Sâncraiu commune, gave up cattle breeding. In 2010, as the number of cows dropped significantly, the diary company quit collecting the milk from the village. So that the villagers could keep their cows and maintain the low income from milk vending (for some of crucial importance), the Protestant priest of the community decided to help out his parishioners and started to produce matured cheese (Figure 4). He regularly purchases the milk from the owners of the 22 cows in the village, completes it with sheep milk from his own flock, produces cheese, matures it in the cellar of the parish house and distributes it through direct marketing and also through the "Gustare" network.

This system of direct marketing works particularly well, the immediate contact between producer and consumer ensures an efficient adjustment to the demand, the consumers receive fresh and healthy products, and it enables to establish a fair price and a sure income for the farmer.

${ }^{1}$ As defined by Social Economy Europe (former European Standing Conference of Cooperatives, Mutual societies, Associations and Foundations, CEP -CMAF; see also http://www.socialeconomy.eu.org/who-see). 


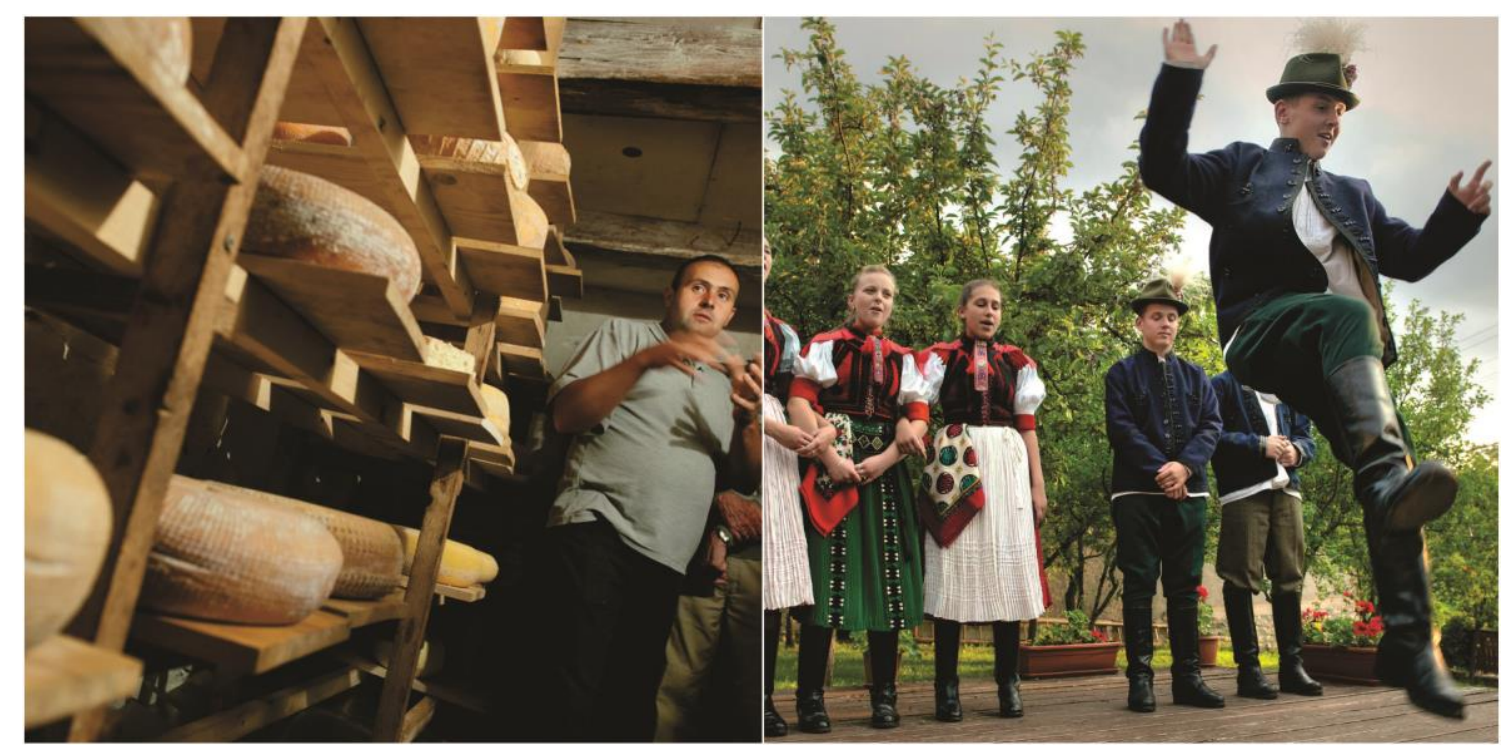

Figure 4: Sâncraiu - cheese maturing in the cellar of the parish house in Alunişu (left, 2016); Demonstration of a traditional dance (right, 2014)

Photos courtesy of Michael Schneeberger

Social entrepreneurship in general, founded on the principles of solidarity and collective involvement, generates jobs and a better quality of life, and offers a framework suited to new forms of enterprise, work, and responsible consumption.

In this manner, it also plays an important role in regional and local development and contributes to the key European Union's priorities and strategic objectives, such as: smarter, sustainable and inclusive development, social cohesion, employment and the fight against poverty, participatory democracy, better governance, sustainable development, etc. (http://www.socialeconomy.eu.org/who-see).

These social and solidarity economy practices have an important development potential in Romania, therefore the focus should be on endogenous resources and on their exploitation in an integrated system, with citizens' involvement and for the communities' general well-being.

As shown above, in both cases, we can notice the ability to activate the human and natural resources as development strategy in rural areas, the implications of entrepreneurship and active participation, yet with several differences. The analysed elements are summarised in Table 1. 
Table 1: Overview of the case studies according to the main criteria for comparison

\begin{tabular}{|c|c|c|}
\hline & Sâncraiu (Hungarian: Kalotaszentkirály) & Lemnia (Hungarian: Lemhény) \\
\hline Strategy & $\begin{array}{l}\text { activation of local human and natural } \\
\text { potential }\end{array}$ & $\begin{array}{l}\text { activation of local human and natural } \\
\text { potential }\end{array}$ \\
\hline Entrepreneurship & $\begin{array}{l}\text { social entrepreneurship; } \\
\text { rather need-driven }\end{array}$ & mainly opportunity-driven \\
\hline $\begin{array}{l}\text { Innovative } \\
\text { approaches }\end{array}$ & $\begin{array}{l}\text { rural space pioneers, direct marketing } \\
\text { system of agricultural products }\end{array}$ & $\begin{array}{l}\text { application of acquired foreign know- } \\
\text { how; willow (Salix viminalis) as } \\
\text { renewable energy plant; relationship } \\
\text { entrepreneur-employees in the case of } \\
\text { S.C. Toro Impex S.R.L.; diversification } \\
\text { trend in the cultivation of crops and } \\
\text { animal breeding }\end{array}$ \\
\hline $\begin{array}{l}\text { Foreign know- } \\
\text { how }\end{array}$ & $\begin{array}{l}\text { on-site input, knowledge, skills } \\
\text { exchange based on reciprocity }\end{array}$ & $\begin{array}{l}\text { imported; employed in market- } \\
\text { oriented agriculture activities }\end{array}$ \\
\hline Tourism & $\begin{array}{l}\text { strong; based upon cultural and } \\
\text { natural resources }\end{array}$ & Insignificant; unused potential \\
\hline Agriculture & $\begin{array}{l}\text { direct marketing system for semi- } \\
\text { subsistence, small-scale farmers }\end{array}$ & $\begin{array}{l}\text { market-oriented SMEs; crop } \\
\text { production and animal breeding; } \\
\text { process of agricultural products }\end{array}$ \\
\hline Capital & little capital input & $\begin{array}{l}\text { important foreign capital input, EU } \\
\text { grants }\end{array}$ \\
\hline Leadership & $\begin{array}{l}\text { associations, strong personalities, } \\
\text { local municipality }\end{array}$ & one main economic stakeholder \\
\hline Associations & cultural, economic, and environmental & youth organisation \\
\hline
\end{tabular}

\section{CONCLUSIONS}

A series of success factors enabled the development of the two analysed rural communities and of their neighbourhood: a bottom-up approach of development, enhanced spirit of entrepreneurship, experience and networking within the commune and abroad, more or less available financial resources. Both communes demonstrate a high degree of entrepreneurship, but, in Lemnia, is notably motivated by opportunity and, in Sâncraiu, rather pushed by need. Regardless of the motivation, these examples demonstrate the possibilities that know-how transfer and personal relationships, based on trust or even friendship, bear for the development of rural communities, exploiting the local human and natural potential. The improvements have positive impact not only on the target community, but also on the surrounding communes.

The case of Sâncraiu illustrated also the significant role that social entrepreneurship initiatives could have in regional and local development, because of their principles of sustainable and inclusive development and due to measures addressed to mitigate poverty.

The surveyed innovative inputs of in-migrants need rather small financial investment and due to community members' involvement, they contribute to social cohesion and have community building effects. Trust can transform social networks into social capital and results in valuable resource in the shape of information, capital, labour, etc. The rural space pioneers form relevant 
stakeholder groups which assist in the revitalization of affected areas and communities, and their successful activities could inspire valuable human resources to join their endeavour or even other communities to develop initiatives adjusted to their own needs. In several western European countries (e.g. Germany, the Netherlands, and Spain), policy makers and public administrations acknowledge the significant contribution of space pioneers to alleviate the effects of structural changes in rural areas (Faber \& Oswalt, 2013). The public administration, by supporting and encouraging these innovative initiatives, could help improve the quality of life of the affected communities. The state authorities should create conditions which enable citizens to productively engage in their local community.

The most successful approach would surely be the co-operation between civil society and municipalities, as well as with the private sector. The support from the public administration has to be available in time, whereat the administration has to be open-minded. This collaboration process creates also a culture of individual responsibility within the community which increases the efficiency of the measures.

The findings of the case studies endorse the policy recommendations defined by the OECD and presented in Potter and Hofer (2009) to enhance rural entrepreneurship. For a successful rural entrepreneurship, we would like to underline the following: (1) promote and implement an integrated approach to rural development; (2) find innovative ways of increasing access to business services for new and existing entrepreneurs in areas of low population density; (3) promote networking activities between entrepreneurs, potential entrepreneurs and key institutions in rural areas; (4) encourage farmers to diversify into non-farming activities; (5) focus on identifying local and regional assets and converting them into entrepreneurial activity; (6) implement entrepreneurship education programs; (7) generate local community support for entrepreneurship; (8) organise support services for entrepreneurs into effective networked systems for providing resources such as technical assistance and training, access to capital, land and buildings, and regulatory guidance; (9) connect rural entrepreneurs to external markets, regionally, nationally, and internationally so that they are not dependent upon stagnant local markets for their goods and services (Potter \& Hofer, 2009, p. 191).

Taking into account the Romanian policies of rural development focusing on the economic and social sustainability of the affected areas, these recommendations should be considered in the process of creating regulations and implementing entrepreneurship supportive measures.

\section{REFERENCES}

COMMISSION OF THE EUROPEAN COMMUNITIES (2003). Green Paper. Entrepreneurship in Europe, Retrieved August 3 2016, from http://ec.europa.eu/invest-inresearch/pdf/download_en/entrepreneurship_europe.pdf

DELFMANN, H., KOSTER, S., McCANN, Ph., \& VAN DIJK, J. (2014). Population Change and New Firm Formation in Urban and Rural Regions. Regional Studies, 48(6), 1034-1050.

FABER, K., \& OSWALT, PH. (eds.) (2013). Raumpioniere in ländlichen Regionen. Neue Wege der Daseinsvorsorge [Space Pioneers in Rural Regions. New Ways of Ensuring Public Services]. Spector Books: Leipzig.

FRITSCH, M., \& WYRWICH, M. (2014). The Long Persistence of Regional Levels of Entrepreneurship: Germany, 1925-2005. Regional Studies, 48(6), 955-973. 
HAVADI-NAGY, K.X. (2014). "Wir brauchen Gummistiefel und Supermannkostüm”. Raumpioniere im ländlichen Raum Rumäniens ["We Need Rubber Boots and the Superman Costume”. Space Pioneers in the Rural Regions of Romania]. In: BENEDEK, J., \& PETREA, D. (eds.), Un capitol nou al Şcolii Geografice Clujene. Eckart Wilfried Schreiber la 70 de ani de viaţă (pp. 263-276). Cluj-Napoca: Presa Universitară Clujeană.

HAVADI-NAGY, K.X., JORDAN, P., ILOVAN, O.-R., ZAMETTER, TH.FR., CRISTEA, M., \& SEBESTYÉN, T.-T. (2015). The Sustainable Development of Less-Favoured Rural Areas: A Study of the Romanian and Austrian Experiences. Romanian Review of Regional Studies, 11(2), 19-30.

http://www.kalotaszeg-davincze.ro/en, Retrieved August 32016.

http://www.socialeconomy.eu.org/who-see, Retrieved August 32016.

JORDAN, P., HAVADI-NAGY, K.X., \& MAROŞI, Z. (2016). Tourism as a Driving Force in Rural Development: Comparative Case Study of Romanian and Austrian Villages. TOURISM - An International Interdisciplinary Journal, 64(2), 203-218.

KIBLER, E., KAUTONEN, T., \& FINK, M. (2014). Regional Social Legitimacy of Entrepreneurship: Implications of Entrepreneurial Intention and Start-up Behaviour. Regional Studies, 48(6), 995-1015.

NATIONAL INSTITUTE FOR STATISTICS, ROMANIA (2013). Rezultatele finale ale Recensământului din 2011: "Tab 8. Populația stabilă după etnie - județe, municipii, orașe, comune" [Final Results of the Population Census of 2011: Table 8. Population by Residence according to Their Ethnic Affiliation At the Level of Counties, Cities, Towns, and Communes], Retrieved August 3 2016, from http://www.recensamantromania.ro/wp-content/uploads/2013/07/sR_Tab_8.xls

PIJNENBURG, K., \& KHOLODILIN, K.A. (2014). Do Regions with Entrepreneurial Neighbours Perform Better? A Spatial Econometric Approach for German Regions. Regional Studies, 48(5), 866-882.

POTTER, J., \& HOFER, A.R. (eds.) (2009), Strengthening Entrepreneurship and Economic Development in East Germany: Lessons from Local Approaches. Paris: Organisation for Economic Co-operation and Development, Retrieved August 3 2016, from http://www.oecd.org/site/cfecpr/42367462.pdf

ROMANIAN GOVERNMENT, MINISTRY FOR AGRICULTURE AND RURAL DEVELOPMENT (2013). Programul Național de Dezvoltare Rurală 2007-2013 [National Rural Development Programme 2007-2013], Retrieved August 3 2016, from http://www.madr.ro/docs/dezvoltare-rurala/PNDR_20072013_versiunea-consolidata-nov2013.pdf

ROMANIAN GOVERNMENT, MINISTRY FOR AGRICULTURE AND RURAL DEVELOPMENT (2015). Programul Național de Dezvoltare Rurală pentru perioada 2014-2020 [National Rural Development Programme 2014-2020], Retrieved August 3 2016, from http://www.madr.ro/docs/dezvoltarerurala/programare-2014-2020/PNDR-2014-2020-versiunea-aprobata-26-mai-2015.pdf

SMALLBONE, D. (2009). Fostering Entrepreneurship in Rural Areas. In: POTTER, J., \& HOFER, A.R. (eds.), Strengthening Entrepreneurship and Economic Development in East Germany: Lessons from Local Approaches (pp. 161-187). Paris: Organisation for Economic Co-operation and Development, Retrieved August 3 2016, from http://www.oecd.org/site/cfecpr/42367462.pdf

WESTLUND, H., LARSSON, J.P., \& RADER OLSSON, A. (2014). Start-ups and Local Entrepreneurial Social Capital in the Municipalities of Sweden. Regional Studies, 48(6), 974-994. 